Ann. Biol. anim. Bioch. Biophys., 1979, 19 (6), 1801-1806.

\title{
Age of Microcebus murinus at the onset of testicular development : Preliminary observations on photoperiodic effect
}

\author{
par Arlette PETTER-ROUSSEAUX \\ Laborafoire d'Ecologie, Equipe de Recherches sur les Prosimiens \\ Muséum National d'Histoire Naturelle \\ 4, avenue du Petit-Château, 91800 Brunoy, France.
}

Summary. After weaning, the prepuberal Microcebus born under long daylength was exposed to one of three photoperiodic conditions :

1) short daylengths after 4 to 6 postnatal months under long daylength ;

2) 1 month of short daylengths at the age of 2 months, then long daylengths ;

3) low, constant red light at the age of $11 / 2$ months. Testicular development was first observed between 130 and 313 days, depending on the experimental conditions. Under short daylenghts, the earlier the animals were exposed, the earlier the testis developed ; long daylength was stimulating if preceded by short daylength.

\section{Introduction.}

The age of seasonally reproducing animals at sexual maturation varies among individuals of the same species, being related, on one hand, to the actual age of the animal and, on the other, to the time of its birth during the season. It has often been noted in domestic ungulates, for example, that young born at the beginning of the reproductive season reach sexual maturity in the year of their birth, while those born at the end of the season only become mature the following year, the photoperiod being unfavorable when they attain the proper age (Sadleir, 1969 ; Dyrmundson, 1973 ; Courot et al., 1975 ; Land, 1978).

This is also the case of small mammals such as rodents and insect-eaters. The testis of the hedgehog, for example, enlarges in the spring whether the animal is born in the spring or the fall, since there is an involution phase from September to December (Saboureau, 1976). In the microcebus, or mouse lemur, a small noctural primate of Madagascar living in captivity in natural daylight in the northern hemisphere, testicular development begins after birth in January; an animal born at the end of May becomes sexually active during its 8th month, while one born at the end of August becomes sexually active during its 5 th month. Testicular development is thus possible from the age of 5 months, and an external factor, possibly photoperiodism, plays a role in this development. However, previous experiments (PetterRousseaux, 1970,1972, 1975) have shown that photoperiods longer than 12 hrs induced sexual activity in resting animals, and that short ones caused sexual rest in active 
animals. Since mouse lemurs born very early in the season could be submitted to long photoperiods before winter, we wondered what effect such daylengths would have on impuberal animals, and at what age they could respond to such stimulation.

\section{Methods.}

The rearing conditions of Microcebus murinus have already been described (PetterRousseaux, 1970).

Mouse lemurs grow very regularly during the first two postnatal months, attaining a body weight of 60 to $70 \mathrm{~g}$ at the end of that time. Normal ponderal growth is achieved during the 3rd month; afterwards, the body weight varies seasonally (Petter-Rousseaux, 1970, 1974). Weaning takes place at about $11 / 2$ month.

Testicular development was estimated by regular palpation of the scrotum once or twice a week. We considered the time when the testis felt hard to the touch and could be clearly distinguished by palpation as the age of first testicular development ; 15 days later it reached a length of 10 to $15 \mathrm{~mm}$, and after one month 20 to $22 \mathrm{~mm}$. Linear measurements were taken with a caliper square having a $2 \mathrm{~mm}$ precision.

The experiments were carried out in an artificially lighted animal room, using an annual photoperiod varying between 10 and $14 \mathrm{hrs}$, which shifted in relation to the natural rhythm, so that «summer » in the animal room began 4 months earlier than the true summer outdoors. The hours in this room were changed every 15 days; the young were born in long daylight ratio (about $14 \mathrm{hrs}$ ) and reached 3 months of age about when the daily light ratio was less than $12 \mathrm{hrs}$.

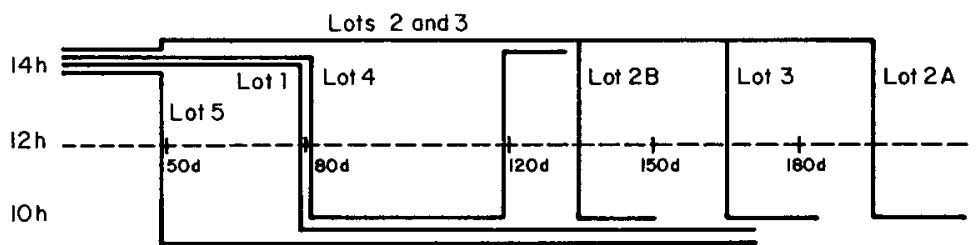

FIG. 1. - Pholoperiodic treafments applied to different lots of Microcebus murinus after weaning.

Lot 1 : control animals remaining in the animal reproduction room; Lots 2 and 3 : animals remaining a long time under long daylength; Lot $4:$ animals exposed to short daylength periods before being submitted again to long daylength; Lot 5 : animals exposed to constant low red light.

Five lots of impuberal animals were submitted to the following treatments, shown diagramatically in figure 1 :

Lot 1 (controls) : 9 males were continually exposed to the photoperiodic variations of the animal reproduction room where the daylight ratio was $12 \mathrm{hrs}$ when the animals reached a mean age of 81 days.

Experimental lots.

1) Animals not submitted to a photoperiod of 12 hrs or less during the natural decrease of the animal room daylight ratio during the third month : 
Lot 2 : at weaning at a mean age of 50 days, 7 males were removed from the animal room where they were still under long daylength, and were exposed to the natural outdoor light in Paris either (i) at the beginning of May (15 hr daylength ; 3 animals, lot 2-A, which thus remained at long daylength until $61 / 2$ months of age at the end of September), or (ii) at the beginning of July (16 hr daylength ; 4 animals, lot 2-B, which were thus exposed to long photoperiod until $41 / 2$ months of age).

Lot 3 : at a mean age of 83 days, 3 animals were removed from the animal room, where they were still in long photoperiod, and were exposed to the natural outdoor light in July; they thus remained under long daylight ratio until $51 / 2$ months of age.

2) Animals submitted to long daylength after having been under photoperiods of less than $12 \mathrm{hrs}$ during the normal photoperiodic decrease in the animal room between 80 and 100 days.

Lot 4 : at a mean age of 117 days, 11 males were removed from the animal room while the daylength was at the most $12 \mathrm{hrs}$ for $11 / 2$ month; they were then submitted either (i) to the natural outdoor light in Paris (15 hr daylength ; 5 animals, Lot 4-A) or (ii) to the same length of artificial lighting (6 animals, Lot 4-B).

3) Animals removed from the effect of photoperiodism.

Lot 5 : at weaning between 45 and 55 days, 8 males were removed from the animal room when they were still under long daylength and were exposed to constant, low-intensity red light, which did not hinder the locomotor activity of these noctural animals.

The different lots were compared to 8 males born and raised under natural daylight between May and September.

\section{TABLE 1}

Effect of experimental photoperiodic treatments on age at onset of testicular development in Microcebus murinus. Age in days, weight in grams. Means and mean confidence intervals for $\mathbf{P}=0.05$.

\begin{tabular}{|c|c|c|c|c|c|c|}
\hline & $\begin{array}{l}\text { Age at the } \\
\text { beginning } \\
\text { of the } \\
\text { experiment }\end{array}$ & $\begin{array}{c}\text { Age at onset } \\
\text { of daylengths } \\
\text { of } 12 \mathrm{~h} \text { and } \\
\text { less }\end{array}$ & $\begin{array}{l}\text { Age at onset } \\
\text { of testicular } \\
\text { development }\end{array}$ & $\begin{array}{l}\text { Body weight } \\
\text { at onset of } \\
\text { testicular } \\
\text { development }\end{array}$ & $\begin{array}{c}\text { No. of days } \\
\text { under a day- } \\
\text { length of } 12 \mathrm{~h} \\
\text { and less before } \\
\text { development }\end{array}$ & $\begin{array}{l}\text { No. of days } \\
\text { under a day- } \\
\text { length of } \\
\text { more than } \\
12 \mathrm{~h} \text { before } \\
\text { development }\end{array}$ \\
\hline 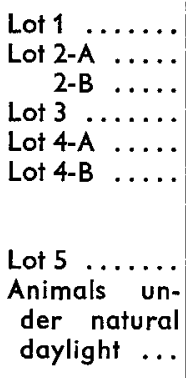 & $\begin{array}{r}-\overline{ } \\
49.86 \pm 6.04 \\
83.33 \pm 18.38 \\
116.91 \pm 6.71\end{array}$ & $\begin{array}{r}81.11 \pm 6.85 \\
4199.33 \pm 4.66 \\
130.25 \pm 21.15 \\
167.33 \pm 18.78 \\
72.09 \pm 6.85\end{array}$ & $\begin{array}{l}177.44 \pm 5.78 \\
312.67 \pm 51.15 \\
237.50 \pm 10.51 \\
264.67 \pm 8.80 \\
130.60 \pm 14.78 \\
130.50 \pm 9.57 \\
\\
152.25 \pm 11.08 \\
185.13 \pm 20.28\end{array}$ & $\begin{array}{c}107.89 \pm 13.50 \mathrm{~g} \\
108.67 \pm 85.30 \\
98.75 \pm 19.58 \\
127.33 \pm 23.29 \\
67.20 \pm 4.24 \\
73.83 \pm 13.34 \\
\\
60.75 \pm 6.55 \\
85.13 \pm 13.70\end{array}$ & $\begin{array}{c}96.33 \pm 6.53 \\
113.33 \pm 54.58 \\
107.25 \pm 19.27 \\
97.33 \pm 12.32 \\
45 \text { days fol- } \\
\text { lowed by day- } \\
\text { lengths longer } \\
\text { than } 12 \mathrm{~h} \\
104.75 \pm 9.36 \\
\\
104.38 \pm 17.45\end{array}$ & $\begin{array}{l}11.60 \pm 5.09 \\
15.33 \pm 4.13\end{array}$ \\
\hline
\end{tabular}




\section{Results.}

All the animals matured sexually, but at different times ranging from a mean 130 days for lot 4 to more than a mean 300 days for lot 2A (table 1). Their body weight was between $61 \mathrm{~g}$ (mean of lot 5 : first testicular development at 152 days) and $127 \mathrm{~g}$ (mean of lot 3 : first festicular development at 262 days).

The animals fell into two groups according to the time of first testicular development : (i) at photoperiods of less than $12 \mathrm{~h}$ (lots 1, 2, 3, 5, as well as animals raised under natural daylight), (ii) at daylength longer than $12 \mathrm{~h}$ (lot 4). It would seem that age of first testicular development depended on the age at wich the animal was removed, for the first time in its life, from the long photoperiod under which it was born (fig. 2).

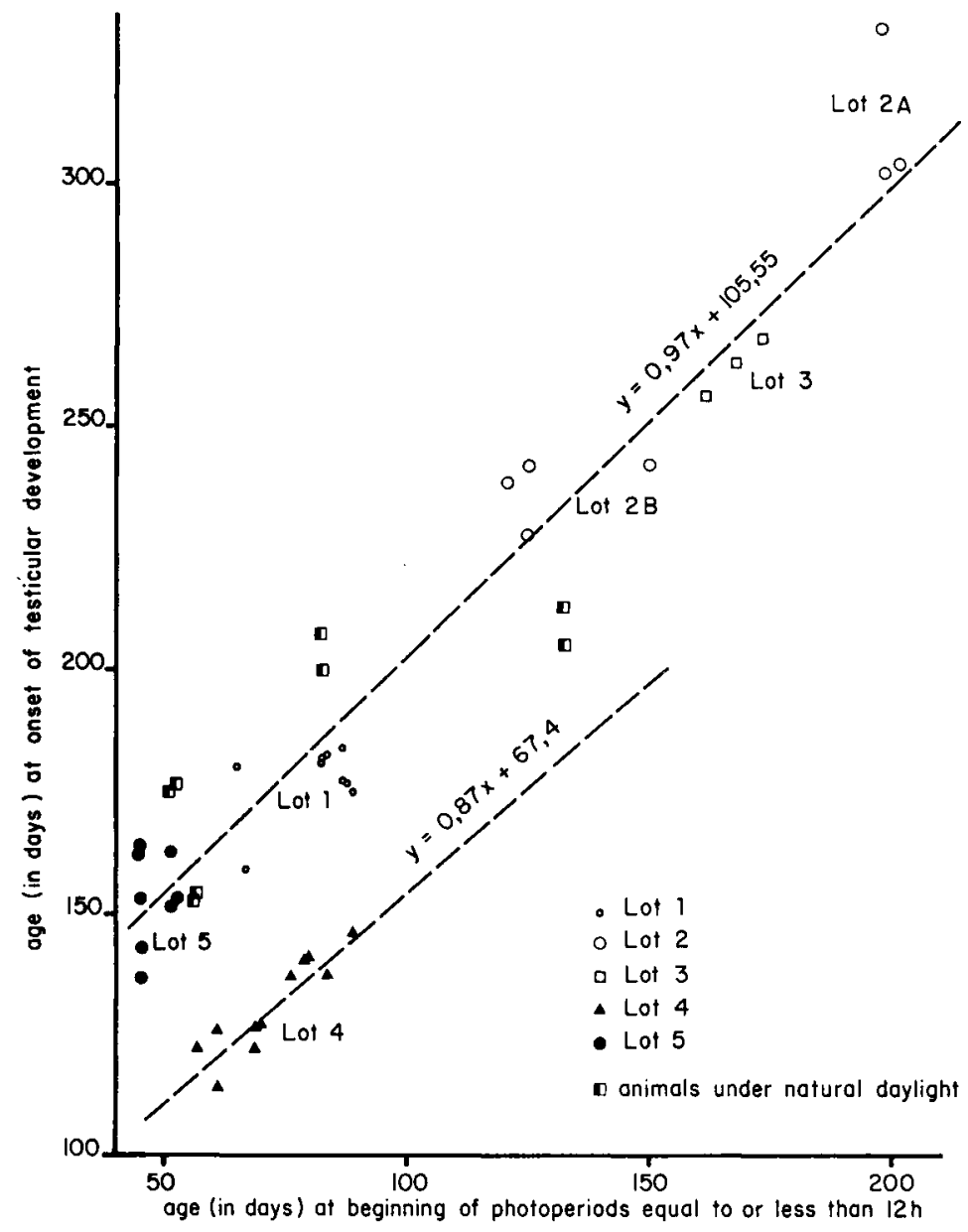

FIG. 2. - Effect of age during short daylength period on age at onset of testiculor development in Microcebus murinus. 
The graph in figure 2 shows two straight parallel lines (lot 4 slope : 0.87 ; slope of lots $1,2,3,5$ together : 0.97). There is a high correlation in both cases : 0.90 (P 99 p. 100) for lot 4 and 0.96 (P 99 p. 100) for lots 1, 2, 3, 5.

\section{Discussion.}

These results show that sexual maturation is not directly related to body weight, which varied with the age at which the animal reached that maturity.

In lots 1, 2, 3, 5 and the animals raised under natural daylight, first testicular development occurred a mean 103 days after the photoperiods had reached 12 hrs or less, and thus the earlier after weaning that short daylength was applied. This duration of some 100 days occurred in the annual cycle between the beginning of October and the month of January, the time at which the testis began to grow after annual rest. The testicular development faking place in January in the young and the adults would thus have similar determinism, and would not be due to the beginning increase of natural photoperiods.

Lot 4 animals showed first testicular development a mean 12 and 15 days after exposure to long daylength; this development took place a mean 57 and 60 days after they had been under periods equal to and lower than $12 \mathrm{~h}$ previously; this duration was much shorter than the 103 days of the preceding lots. In fact, we observed a minimum of $96.33-6.53=89.90$ days for the control lot, $104.75-9.36=95.39$ days for lot 5 , and, at the most, $60.33+4.13=70.46$ days for lot $4 B$. Long photoperiods were thus stimulating.

A comparison of lot 4 and lot 2 suggests that long photoperiod may not stimulate if the animal has not been sensitized by short days first ; however, we cannot exclude the possibility of the inhibitory effect of a shortening daylight ratio (although higher than $12 \mathrm{~h}$ ) to which lot 2 animals were submitted at the age at which development occurred in the others.

The minimum age of testicular development which we obtained was 130 days. It is quite possible that this age could be lowered, if the animals were submitted to short days earlier, and especially if the sensitization period preceding the long stimulatory photoperiods was reduced.

In mammals in which the sex glands are stimulated by long days, the response of the young is often immediately identical to that of the adults : in rodents, long daylight ratio accelerates puberty anyway (Sadleir, 1969); in Microtus arvalis, puberty is reached more quickly under a daily $15 \mathrm{hr}$ light schedule from birth than under a $10 \mathrm{hr}$ one (Martinet, 1963).

In the golden hamster, which resembles Microcebus in its other reactions to photoperiodic variation, sexual maturity is obtained at about 10 weeks of age, whatever photoperiodic treatment is applied from 4 weeks of age to animals born in winter (Gaston and Menaker, 1967) ; there is thus a wide divergence between the two species.

In Phodopus sungorus, animals kept from birth under $16 \mathrm{hr}$ photoperiods reach sexual maturity much earlier than those kept under $8 \mathrm{hr}$ photoperiods (sexual maturity at 130 days) (Hoffmann, 1978). On the other hand, in the ferret which, as Microcebus, 
is stimulated by long days while the young reach maturity during decreasing daylength (Boissin, 1976), Bissonette in 1935 (cited by Sadleir, 1969) noticed retarded puberty in long days, which was either advanced or retarded in shorf days. This species would thus resemble Microcebus.

Endocrinological studies will permit a comparison between this "refractory " state observed in the young in relation to the long daylight ratio and that occurring in the adults when stimulation has lasted several months (Petter-Rousseaux, 1975).

Reçu en ovril 1979

Accepté en juin 1979.

Résumé. Des Microcèbes impubères, nés en photopériode longue, ont subi après le sevrage 3 types de traitements photopériodiques différents : 1) un séjour de 4 à 6 mois en photopériodes supérieures à $12 \mathrm{~h}$, suivi de photopériodes inférieures à $12 \mathrm{~h}, 2$ ) 1 mois de photopériodes inférieures à $12 \mathrm{~h}$ à l'âge de 2 mois, suivi de photopériodes supérieures à $12 \mathrm{~h}, 3$ ) un séjour en lumière très faible et constante à partir de l'âge de 1 mois $1 / 2$. Le premier développement testiculaire a eu lieu à un âge variant entre 130 et 313 jours : en l'absence de stimulation par une photopériode longue, il est d'autant plus précoce que le passage en jours courts a été précoce ; d'autre part, les photopériodes supérieures à $12 \mathrm{~h}$ l'accélèrent, à condition d'avoir été précédées par des photopériodes courtes.

\section{References}

BISSONNETTE T. H., 1935. Modifications of Mammalian cycles. II. Effects upon young males ferrets (Putorius vulgaris) of constant eight one half hour days and of six hours illumination after dark, between November and June. Biol. Bull. Mar. Biol. Lab. Woods Hole, 68, 300-313.

BOISSIN L., 1976. Photorégulation du cycle sexuel chez le furet mâle. Etude préliminaire. Bull. Soc. Ecophysio., 1, 22.

COUROT M., de REVIERS M. M., PELLETIER J., 1975. Variations in pituitary and blood LH during puberty in the male lamb. Relation to time of birth. Ann. Biol. anim. Bioch. Biophys., 15, 509-516.

DYRMUNDSON O. R., 1973. Puberty and early reproductive performance in sheep. Anim. Breed. Abstr., 41, 273-279 et 419-430.

GASTOON S., MENAKER M., 1967. Photoperiodic control of Hamster testis. Science, 158, 925-928.

HOFFMANN K., 1978. Effects of short photoperiods on puberty, growth and moult in the Djungarian Hamster (Phodopus sungorus). J. Reprod. Fertil., 54, 29-35.

LAND R. B., 1978. Reproduction in young sheep : some genetic and environmental sources of variation. J. Reprod. Fertil., 52, 427-436.

MARTINET L., 1963. Ełablissement de la spermatogenèse chez le Campagnol des champs (Microtus arvalis) en fonction de la durée quotidienne d'éclairement. Ann. Biol. anim. Bioch. Biophys., 3, 343-352.

PETTER-ROUSSEAUX A., 1970. Observations sur l'influence de la photopériode sur l'activité sexuelle chez Microcebus murinus (Miller, 1777) en captivité. Ann. Biol. anim. Bioch. Biophys., 10, 203-208.

PETTER-ROUSSEAUX A., 1972. Application d'un système semestriel de variations de la photopériode chez Microcebus murinus. Ann. Biol. anim. Bioch. Biophys., 12, 367-375.

PETTER-ROUSSEAUX A., 1974. Photoperiod, sexual activity and body weight variations of Microcebus murinus (Miller, 1777), 365-373. In MARTIN R. D., DOYLE G. A., WALKER A. C., Prosimian Biology, Duckworth, London.

PETTER-ROUSSEAUX A., 1975. Activité sexuelle de Microcebus murinus soumis à des régimes photopériodiques expérimentaux. Ann. Biol. anim. Bioch. Biophys., 15, 503-508.

SABOUREAU M., 1976. Variations saisonnières du fonctionnement testiculaire chez le hérisson. Bull. Soc. Ecophysio., 1, 20.

SADLEIR R. M. F. S., 1969. The ecology of reproduction in wild and Domestic mammals. Methuen and Co LTD. London. 